\title{
レーザフラッシュ法による炭素材料の熱拡散率測定 Thermal Diffusivity Measurements of Carbon Materials by a Laser Flash Technique
}

馬場哲也

\section{1.はじめに}

熱拡散率 $\alpha$ は熱伝導率 $\lambda$, 比熱容量 $\mathrm{c}$, 密度 $\rho$ から $\alpha=\lambda /(\mathrm{c} \rho)$ によって定義される。単位は $\left[\mathrm{m}^{2} \mathrm{~s}^{-1}\right]$ である。熱拡散率は非 定常熱伝導に伴う量で直観的には温度分布の変わりやすさを 表しており，その值は試料を非定常的に加熱したときの温度 変化から求められる。熱拡散率測定法には試料形状および試 料の非定常加熱法, 測温位置と測温法の組み合わせにより多 くの種類があるが, 今日では熱拡散率データの大部分はレー ザフラッシュ法により求められる1)-3)。熱拡散率測定の意義 は, 熱拡散率自体を知ることに加えて密度 $\rho$ および示差走査熱 量計 (DSC) 等により別途求めた比熱容量cの值を用いて $\lambda=$ $\alpha c \rho に よ り$ 熱伝導率が算出できることにある。

\section{2. 測定の原理}

レーザフラッシュ法は図1に示されるよjに円板状試料の 表面をレーザパルスにより均一に加熱した後の試料裏面温度 変化から熱拡散率を算出する測定法である ${ }^{21}$ 。断熱条件を仮 定した理論解によればパルス加熱後の試料裏面温度は図2の ように上昇し, 試料内の温度分布が均一化されるのに伴い,一 定值に収束する。レーザフラッシュ法は小さい試料を短時間 に測定でき, 解析法が簡明であるため, 熱拡散率の標準的かつ 実用的計測法として広く用いられている。

レーザフラッシュ法による熱拡散率測定装置の代表的構成 は,図1においてパルス加熱光源としてはNd-YAGレーザ, Ndガラスレーザ,ルビーレーザなどが用いられ, 発光の時間幅は $100 \mu \mathrm{s} \sim 1 \mathrm{~ms}$ 程度, 1パルス当りのエネルギーは1〜10Jである。 室温以上の測定を行う場合には真空容器中に保持されヒータ によって加熱される。試料裏面の過渡的温度変化の測定は熱 電対か放射測温により行われるが, 今日では主にInSbなどの 化合物半導体を検出器とした放射計が用いられる。観測され た信号はトランジェントメモリに取り込んでデジタル化し， パソコンにより解析される。熱拡散率の算出は通常下記の条 件を仮定して行われる。(仮定群 (A) とする。)

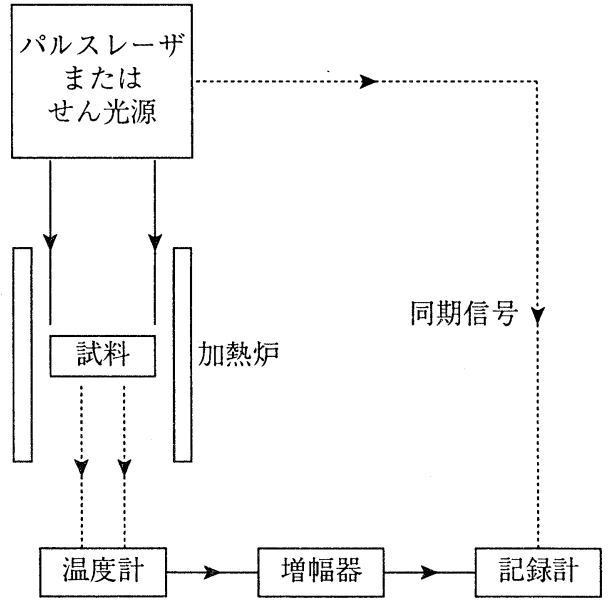

図1 レーザーフラッシュ法熱拡散率測定装置のブロック図

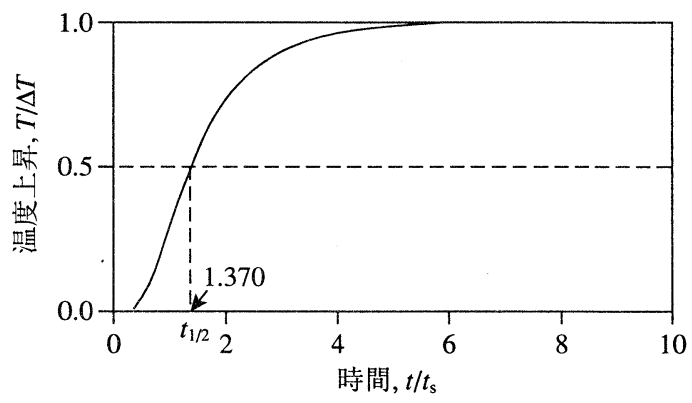

図2 理想条件下におけるパルス加熱後の試料㙜面温度変化

1. 試料表面は瞬間的に加熱される。

2. 試料表面は均一に加熱される。

3. 試料は外界から断熱されている。

4. 試料は均質である。

5. 試料は不透明である。

このとき熱拡散率 $\alpha$ は最大温度上昇値の半分 $\Delta T / 2$ に達するま での時間 $t_{1 / 2}$ から次式により算出される4)。 


$$
\alpha=1.370 d^{2} /\left(\pi^{2} t_{1 / 2}\right)
$$

ここでdは試料の厚さである。このアルゴリズムは $t_{1 / 2}$ 法,また はハーフタイム法と呼ばれる。

室温から $2000^{\circ} \mathrm{C}$ まで温度範囲で稼働するレーザフラッ シュ装置は市販されており, 国内メーカでは, 真空理工(侏), 京 都電子(侏), 海外メーカではNetzsch社 (ドイツ), Anter社(米 国)，Sopra社(フランス)などの製品がある。価格は測定温度 範囲などにより異なるが,およそ1000万円から2000万円程度 である。

\section{3. 測定上の注意}

\section{1）試料の準鞴}

直径 $10 \mathrm{~mm} \phi$ の円板状試料が標準的に用いられる。厚さは $0.5 \mathrm{~mm} \sim 5 \mathrm{~mm}$ 程度であるが, 熱拡散率值の予想值から $t_{1 / 2}=$ $1.370 d^{2} /\left(\pi^{2} \alpha\right)$ を計算し, $t_{1 / 2}$ がおよそ20ms〜100 $\mathrm{ms}$ の範囲に 入る厚さの試料を用いることが望ましい。試料を切り出す際 には表面が十分平滑で両面間の平行度が厚さの $1 \%$ 以内とな るよう注意する。切り出しただけでは不十分な場合には上記 の条件を満たすまで両面を研磨する。金属やセラミックスな どでは試料表面にレーザビームを吸収させるための黒化薄膜 を付着させて測定を行うことが多いが, 黒色の炭素系材料に おいては不要である。

\section{2) 試料厚さの補正}

試料の厚さは室温においてマイクロメータにより測定すれ ば十分である。高温下の測定における熱拡散率の算出にはそ の温度での試料の厚さを知る必要がある。室温における長さ を基準とした温度 $T(\mathrm{~K})$ での線膨張の比率を $\beta$ とすると, 室温 での厚さ $d_{0}$ の試料は $T(\mathrm{~K})$ では厚さ $d_{0}(1+\beta)$ となる。したが って真の熱拡散率は熱膨張補正前の熱拡散率の $(1+\beta)^{2} \sim$ $1+2 \beta$ 倍となる。熱膨張補正を行った場合にはその旨明記し， 未補正の值,および補正に用いた熱膨張率の出典を記載する 必要がある。特に熱膨張の大きい試料や, 超高温での測定を 除き队は熱拡散率の測定精度に比べて小さく, 熱膨張補正は不 必要なことも多い。

\section{3）加熱パルスの時間幅と温度計の応答速度}

レーザフラッシュ法において使用される加熱パルスの時間 幅は通常0.1〜1ms程度であり, $t_{1 / 2}$ が短い（5１0ms程度）試 料を測定する場合には, 加熱パルスの時間幅の影響が無視で きない。このような場合は加熱パルスエネルギーの時間軸に 関する重心を計算し, 重心時刻にエネルギーの集中したデル 夕関数によって加熱されたとみなして解析を行う近似が実用 上有用である5)。熱電対を用いて試料毫面温度変化を測定す る場合には応答速度はかなり遅い。さらに $50 \mathrm{~Hz}$ (西日本で は60Hz）の電源ノイズを除去するためにローパスフイル夕 を通して信号を記録している場合には正確な熱拡散率を測定 することは困難である。
正しく設計された放射温度計の応答速度は通常 $100 \mu \mathrm{s} よ り$ 十分速いが6)，7)，市販のレーザフラッシュ装置では赫外放射 計のS/N比を良くみせるため, ローパスフィル夕を入れて応 答速度が1 msより遅くなっていることがあり，熱拡散率測定 に際して大きな不確かさをもたらす可能性がある。

\section{4）熱放射の非線形性}

熱放射の輝度はプランクの放射則に従い温度上昇とともに 非線形に増大する。したがってレーザパルス照射後の放射計 出力変化は温度変化に比例せず歪を伴う。このような歪は低 温ほど大きく, 特に赤外線検出器を用いた放射計による室温 付近での測定においては主要な誤差要因の一つとなる8)。

図3はレーザフラッシュ法により観測される試料裏面温度 変化の非線形性による歪を計算した結果を示している。横軸 は特性時間 $t_{0}=d^{2} /\left(\pi^{2} \alpha\right)(d$ : 試料の厚さ, $\alpha$ : 試料の熱拡散 率)で規格化した無次元時間, 絴軸は試料の最大温度上昇值 $\Delta T=Q / C(Q:$ 試料の吸収したエネルギー, $C:$ 試料の熱容 量）で規格化した無次元温度上昇である。実線は理想条件下 のレーザフラッシュ法により得られる温度変化を表し, 破線 はパルス加熱前の試料温度が293K, パルス加熱による温度上

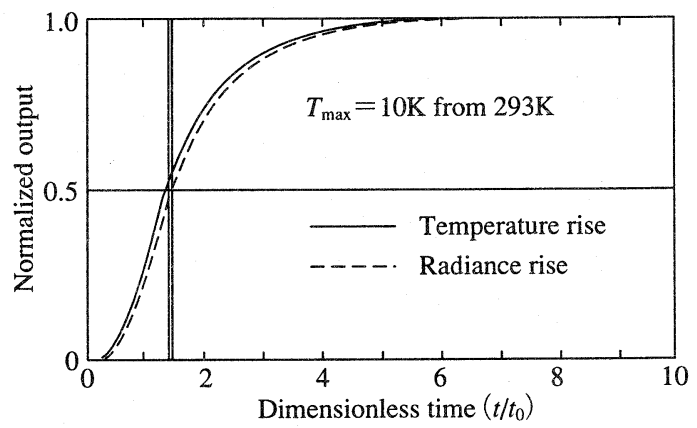

図3試料亭面の温度変化（実線）放射輝度変化（破線）

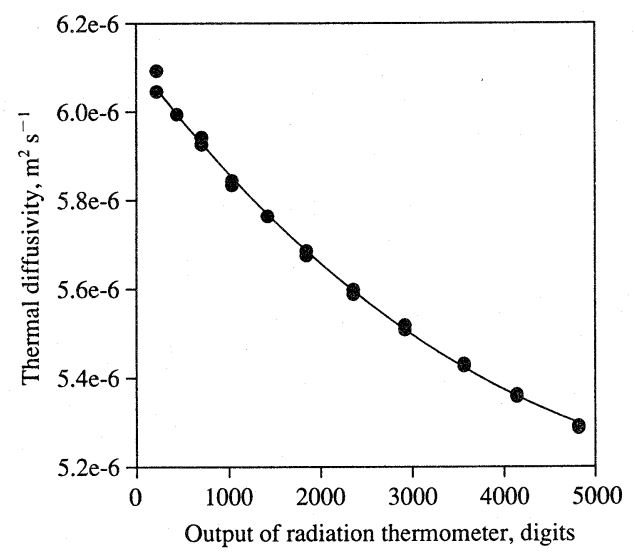

図4 見掛けの熱拡散のパルスレーザ出力依存性 
昇が10Kであるとき, 試料からの分光放射輝度変化に比例し た出力の時間変化を表している。破線は実線より時間遅れを 示し, $t_{12}$ 法により破線から熱拡散率を算出すると $6 \%$ 過小な值 が得られる8)。一般のレーザフラッシュ装置は温度目盛りの 付かない放射計を使用している。この場合には, パルス加熱レ 一ザの出力を変化させて見掛けの熱拡散率を測定し, 出力0 の外挿值から正確な熱拡散率を求めることが現実的である8 この手順で求めた外挿值は, 熱拡散率の温度依存性が無視で きない物質においては, パルス加熱前の定常温度に対応する 熱拡散率に対応している。図4は標準物質候補材料であるグ ラッシーカーボンについて, パルスレーザの出力を変化させ て測定した見掛けの熱拡散率を示している10)。出力を最大約 $6 \mathrm{~J}$ まで増加させると見掛けの熱拡散率は $10 \%$ 以上低下する。 出力を 0 に外挿した熱拡散率は $6.11 \times 10^{-6} \mathrm{~m}^{2} \mathrm{~s}^{-1}$ となる。

\section{5）試料の定常温度}

普及度の高い, 室温 $1500^{\circ} \mathrm{C}$ の温度範囲で稼働するレーザ フラッシュ装置においては試料の定常温度は熱電対により測 定される。熱電対は使用温度範囲や雲囲気などを考慮して選 択する必要がある。また高温測定に際しては熱電対の特性変 化の有無を確認することが重要である。

定常温度測定において最も注意すべき不確かさ要因は試料 と熱電対測温接点の温度差である。加熱炉内の熱交換は熱放 射が支配的であるので, 試料と熱電対測温接点が密着してい ない場合には大きな温度差を生じる可能性がある。実際, 試 料近傍に設置された熱電対の指示值と試料に密着させた熱電 対の指示值が数 $10^{\circ} \mathrm{C}$ 異なった例が報告されている11)。したが って, 試料の定常温度を正確に計測するためには熱電対の測 温接点を試料に密着させる必要がある。それが不可能な簡易 測定装置においては, あらかじめ試料温度と熱電対測温接点 温度の関係を明らかにしておかねばならない。

\section{6) レーザビームの不均一性}

レーザフラッシュ法のパルス加熱に用いられるレーザは大 出力を得るため通常はマルチモード発振の状態で使用され る。したがってその空間エネルギー分布は不均一であること が多い。不均一加熱の影響を受けない高精度測定を行うため にはレーザビームの空間エネルギ分布の均一化が不可欠であ る。最近コア径 $1 \mathrm{~mm}$ 程度の大口径ステップインデックス光 ファイバ内の多重反射により均一ビームを得る手法が確立さ れ熱拡散率測定の高精度化が実現されている(2),13)。

\section{7）試料からの熱損失}

伝導熱損失を抑制するために, 試料との接触面積が小さい 試料ホルダを用いる必要がある。また試料表面からの放射熱 損失は常に存在し, 室温においても無視することはできず, 厳 密には断熱条件は成立しない。特に高温下の測定において は, 熱放射の増大に伴い $t_{122}$ 法では正しい熱拡散率を算出でき ないので, 以下に述べるカーブフィッテング法などにより熱 損失の寄与を考慮した解析を行う必要がある14),15)。

\section{4. データ解析}

以上に述べたように現実の測定では仮定群 $(\mathrm{A})$ に記した理 想条件は成立しない。したがって,これらの仮定の上に成り 立つ $t_{1 / 2}$ 法により算出された熱拡散率は正確ではない。以下で は現実の測定条件に対応したデー夕解析アルゴリズムについ て述べる。

\section{1) 対数法}

試料裏面温度変化の解析解は無限級数で与えられるが, そ の表示法は時間の指数関数を項とする級数と, 時間の逆数の 指数関数を項とする級数の 2 通りある。対数法は後者の級数 の収束が速いことに着目し, 実測された試料裏面温度変化曲 線に級数の第1 項を適合させることにより熱拡散率を算出す るアルゴリズムである(6)，17)。不均一加熱下や熱損失下でも, 比較的正確な熱拡散率が算出できるといわれている。

2) カーブフィッティング法

以上の方法が主に試料裏面温度変化曲線の昇温領域から熱 拡散率を算出するのに対して,カーブフィッティング法はパ ルス加熱後に観測される試料裏面の温度変化曲線全体に理論 式を適合させ, 試料の熱拡散率 $\alpha$ 熱損失を表すパラメータ Biot数 $Y$ とを同時に決定する方法である(8)。この解析では仮 定群 (A)に記したなかで, 条件3.の断熱境界条件を下記の熱損 失境界条件で置き換える。

\section{（3'）試料からの熱損失はNewtonの法則により表せる。 \\ したがって試料表面に対してBiot数が定義できる。}

熱伝導率 $\lambda$, 熱拡散率 $\alpha$, 厚さ $d$ の円板状試料の表面か瞬間的に 均一加熱され，表面と裏面から熱伝達倸数とでニュートンの冷却 則にしたがってパルス加熱前の定常温度へ復帰するときの試 料裏面の温度変化は $t \gg t_{0}$ のとき次式の指数関数に収束する ${ }^{18)}$ 。

$$
\begin{aligned}
& T(t)=\Delta T \cdot A_{0} \cdot \exp \left[-\left(\frac{X_{0}}{\pi}\right)^{2} \cdot \frac{t}{t_{0}}\right] \\
& X_{0}=(2 Y)^{1 / 2}\left(1-Y / 12+11 Y^{2} / 1440\right), \\
& A_{0}=2 \cdot X_{0}^{2}\left(X_{0}^{2}+2 Y+Y^{2}\right)^{-1}
\end{aligned}
$$

ここで特性時間は $t_{0}=d^{2} /\left(\pi^{2} \alpha\right)$, Biot数は $Y=k d / \lambda$ にり定義 される。したがって冷却の時定数 $\tau=\pi^{2} t_{0} / X_{0}{ }^{2}$ は, 実測曲線にお いて $t \gg t_{0}$ の冷却領域に対して，(2) 式の指数関数を最小二乗 法により適合させることにより定まる。したがって $X_{0}^{2} / t_{0}$ が 定まり, 残る可変なパラメータである熱拡散率 $\alpha$ は, 昇温領域 において実測曲線の下にある面積と理論曲線の下にある面積 が一致するように決定され, Biot数 $Y$ も同時に定まる。

カーブフィッティング法によれば実測曲線と理論曲線の一 致の程度から計測の信頼性や算出された熱拡散率の不確かさ を評価できる。 


\section{5. その他}

\section{1）解析プログラム}

カーブフィッティング法に基づく沉用データ解析プログラ ム “CFP32 for Windows” が計量研究所において開発され公 開されている。計量研究所のホームページにアクセスし, ユ 一ザ登録票を送付すれば無料で入手することができる ${ }^{19) 。 ~}$ CFP32 for Windows は Microsoft Windows 95, 98, NT4.0の環 境で動作し, Text file形式で記述された試料裏面温度変化のデ ータをレーザフラッシュ装置の機種に依存せず解析すること ができる。特に国内メーカのデータファイル形式であれば, そのまま読み込むことができる。ただしN88-basic形式のデ 一タには対応していない。

CFP32 for Windowsによれば解析条件を各装置, 測定者, 測 定対象に応じてカスタマイズすることができ，また設定した 解析条件を保存し, 必要時に読み込むことができる。実測さ れた試料裏面温度変化曲線とフィッティングした理論曲線を 重ねて表示するとともに, 両者の偏差を拡大して表示してお り, 両曲線の一致の程度から, 測定の信頼性と算出された熱拡 散率の不確かさを評価することができる。操作はマウスに より画面上でインタラクティブに行うことができる。1つの データの解析に要する時間は1秒以内である。

\section{2）標準物質の頒布}

レーザフラッシュ装置の熱拡散率測定の不確かさは熱拡 散率標準值の与えられた標準物質を測定することにより評 価できる。

これまで熱拡散率標準值の与えられた標準物質は国内・国 外のいずれの機関からも供給されていなかった。そのため米 国国立標準技術研究所 (National Institute of Standards and Technology, NIST）により頒布されている熱伝導率標準物 質・準標準物質が熱拡散率標準物質の代用品として用いられ てきたが, 熱拡散率の標準値が与えられていないため不確か さの評価は困難であった ${ }^{20)}$ 。

このような状況を解決するために, 計量研究所とJFCCは熱 拡散率標準物質に関する共同研究を行った9)。その成果に基 づきJFCCから熱拡散率標準物質として焼結アルミナTD-AL の頒布が開始された ${ }^{211}$ 。室温から $1000 \mathrm{~K}$ の温度範囲で熱拡散 率標準值が与えられており, 熱拡散率標準值の不確かさは包 含係数2 $(95 \%$ 信頼区間) で5.6\%と評価されている。価格は $2 \mathrm{~mm}$ 厚の試料と $3 \mathrm{~mm}$ 厚の試料 2 枚 1 組で 9 万円である。

\section{3）依頼測定}

レーザフラッシュ法による熱拡散率の依頼測定機関として 財団法人ファインセラミックスセンター, 超高温材料研究セ ンター,東レリサーチセンターなどがある。

\section{4）レーザフラッシュ法に関する情報の入手}

レーザフラッシュ法に関するより詳細な説明は, 文献1) - 3) に記述されている。熱伝導方程式の解法, 種々の材料を測定 するための個別技術などのうち以前から知られている知見に 関する文献も挙げられている1)-3)。紙面の制約から割愛した が, レーザフラッシュ法を不均質材料に適用する場合の問題 点の検討 ${ }^{22)}$, 熱処理温度の異なる等方性黑鉛材料の熱拡散率 を系統的に測定しX線回折スペクトルの相関を考察した研究 23), $\mathrm{C} / \mathrm{C}$ 複合材料の熱拡散率を $2300^{\circ} \mathrm{C}$ 超高温まで測定した 結果 ${ }^{24)}$ について文献を示す。

一方, 近年開発された新規技術, 解析手法の進歩, 測定のノ ウハウ,トラブル対策などに関しては, 印刷された文献により 最新の情報を入手することは容易ではない。計量研究所では レーザフラッシュ法に関するホームページを開設し, 情報の 機動的な提供を試みる計画である25)。

\section{文 献}

1）高橋洋一, 熱物性, 1 (1987) 3-12.

2）馬場哲也,レーザフラッシュ法（第1章 固体材料の熱 伝導率および熱拡散率の測定法) 熱物性值測定法日本 機械学会編（養賢堂）(1991）5-13.

3）馬場哲也, 熱拡散率 (10. 関連する物性量の測定), 第4 版実験化学講座, 第4巻熱·圧力日本化学会編（丸善）, (1992) 428-436.

4) W. J. Parker et al., J. Appl. Phys., 32 (1961） 1679-1684.

5) T. Azumi, Y. Takahashi, Rev.Sci.Instrum., 43 (1972) 781.

6）小林正信, 馬場哲也, 小野晃, 熱物性, 8 （1994）143-145.

7）石井順太郎, 馬場哲也, 熱物性（投稿中）.

8）馬場哲也, 小林正信, 小野晃, 熱物性, 7 （1993）156-159.

9）小川光恵他, 12 (1998) 114-119.

10) T. Baba, A. Ono, Proc. 4th Asian Thermophysical Properties Conf., (Tokyo, 1995) 581-584.

11）超高温環境下に㧊りる計測技術調査」(新エネルギー。 産業技術総合開発機構 (1993).

12) T. Baba, J. H. Hong, A. Ono, Proc. 2nd Asian Thermophysical Properties Conf., Sapporo (1989) 127-132.

13) T. Baba, et al., Thermochimica Acta (1993) 218-329.

14) A. Cezairliyan, T. Baba, R. Taylor, Int. J. Thermophysics, 15 (1994) 317-341.

15) T. Baba, A. Cezairliyan, Int. J. Thermophysics, 15 (1994) 343-364.

16) H. M. James, J. Appl. Phys., 51 (1980) 4666-4672.

17）李相玄, 寺井隆幸, 高橋洋一, 8 （1994）213-219.

18）馬場哲也, 第17回日本熱物性シンポジウム論文集,つくば (1996) 379-382.

19) http://www.nrlm.go.jp/section/Joho/CFP/

20) NIST Standard Reference Materials Catalogue 199899.http://ts.nist.gov/ts/htdocs/230/232/232.htm

21）熱拡散率測定用標準物質 “TD-AL” カタログ, 財)フィイ ンセラミックスセンター, http://www.jfcc.or.jp/

22）「レーザーフラッシュ法等の非定常法による熱伝導率／ 熱拡散率評価技術調査報告書」(超高温材料研1997-3）.

23) I. Kishimoto, T. Baba, A. Ono, to be bublished in ThermalConductivity 24, Proceedings of the 24th International Thermal Conductivity Conference (Pittsuburgh, 1997).

24）李甫遠, 馬場哲也, 熱物性 12 （1998） 180-185.

25) http://www.nrlm.go.jp/section/Joho/ 